DOI: $10.31249 / \mathrm{rsm} / 2019.02 .15$

\title{
И.С. Ильин
}

\section{ВЗАИМООТНОШЕНИЯ ВААСТИ И ПРАВОСААВНОЙ ЦЕРКВИ В СОВРЕМЕННОЙ РОССИИ}

Аннотация. В статье рассмотрены причины, по которым государственная власть Российской Федераџии заинтересована в активной деятельности Русской православной иеркви (РПЦ), направленной на укрепление традиционных духовнонравственных иенностей (ТДНЦ). Понятие ТДНЦ появляется в риторике власти в результате осознания необходимости религиозной компоненты для сохранения русской культурной идентичности и политической независимости страны. Развитие государственно-церковных отночений (ГЦО) отвечает интересам государственного суверенитета, поскольку привносит духовно-нравственное измерение в политику.

Ключевые слова: государство; власть; суверенитет; РПЦ; Русская православная иеекковь; традиционные духовно-нравственные ценности.

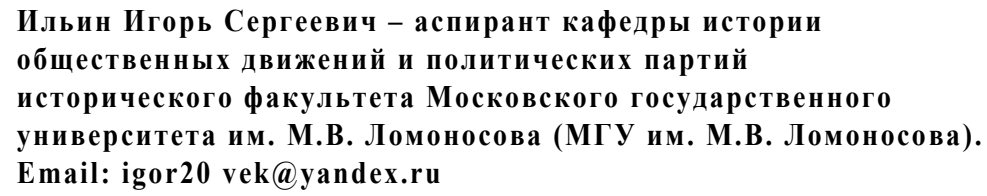

I.S. Ilin. Relations Between the Authorities and the Orthodox Church in Modern Russia

Abstract. The article considers the reasons why the state power of the Russian Federation is interested in a wide activity of the Russian Orthodox Church (ROC) aimed at strengthening traditional spiritual and moral values (TSMV). The concept of TSMV appears in the rhetoric of power as a result of the awareness of the need for a religious component to preserve the Russian cultural identity and political independence of the country. The development of state-church relations (SCR) meets the interests of state sovereignty, as it brings a spiritual and moral dimension to politics.

Keywords: State; power; sovereignty; ROC; Russian Orthodox Church; traditional spiritual and moral values. 


\begin{abstract}
Ilin Igor Sergeevich - Post-Graduate Student of the Department of History of Social Movements and Political Parties of the Faculty of History of Lomonosov Moscow State University. Email: igor20vek@yandex.ru
\end{abstract}

Российское общество, пережив за последние четверть века коренные изменения во всех сферах жизни, вышло на качественно иной уровень государственно-церковных отношений (далее - ГЦО). Государство определяет законодательно-правовую базу взаимоотношений с Русской православной церковью (далее РПЦ) и выстраивает с ней систему взаимодействия.

Православие для современного гражданина России является знаковой ценностью национальной идентичности, формой культурной, исторической, этнической самоидентификации [23]. 67\% граждан РФ полагают, что защищенность чувств верующих важнее свободы самовыражения. Такой показатель является адекватным критерием мягко-традиционалистского общества, оберегающего свои базовые ценности [7]. В настоящее время доля граждан, считающих себя православными, составляет $70-80 \%$ [11; 13; 20]. По словам В.В. Путина, «страна наша, переживая непростые, турбулентные процессы с момента развала Советского Союза, не могла (и страна, и каждый конкретный человек) опираться морально ни на что другое, кроме как на религиозные ценности» [27].

Вопросы, связанные с государственно-церковными отношениями и ролью РПЦ в формировании духовно-нравственных ценностей, находятся в центре различных общественных дискуссий и рассматриваются в политологической, исторической, социологической литературе. Выделим некоторые основные точки зрения.

Ряд авторов утверждает, что одной из основных причин тесного сотрудничества государства с Церковью является поиск ценностного обоснования задач и направлений общественного развития [1]. Отмечается, что лидеры государства видят в православии основу русской цивилизации и национальной идентичности народа $[12 ; 3]$. Подчеркивается, что безопасность государства зависит от системы духовно-нравственных ценностей, господствующей в обществе [17]. Более того, утверждается, что поддержка традиционных ценностей со стороны российского правительства определяет особое место России в глобальной борьбе за традиционные ценности в рамках прав человека на международной арене [35].

В то же время исследователи отмечают тенденцию прагматического подхода государства по отношению к Церкви: оно может как вовлекать ее в свою орбиту в кризисных ситуациях, так и нейтрализовать ее активность в угоду политической конъюнктуре [15]. Использование базовых ценностей в прагматических интересах государства воспринимается частью общества как 
навязывание Церковью идеологического концепта, что противоречит конституции и официальной политической доктрине [33]. По мнению исследователей, этому способствует обмирщение религии, которое сопровождает десекуляризацию общества [34]. Также исследователи отмечают, что СМИ искусственно сформировали «образ монолитной государствообразующей Церкви», который зачастую используется в качестве идеологического инструмента в руках политического режима [18].

Согласно другой точке зрения, Церковь выражает нравственную оценку положенных в основу политики ценностей и принципов, открыто утверждает свою социально-политическую позицию, которая не пересекается с политической конъюнктурой, формирует мировоззрение и взгляды на социальные явления. Государственные лидеры не ставят целью секуляризацию общества, но, наоборот, поддерживают, в том числе лично, Русскую православную церковь. Существует общая заинтересованность Церкви и власти в духовнонравственном воспитании молодежи [12].

Отметим еще одно наблюдение современных авторов. Церковь «нащупала» роль «доверенного посредника» и представителя интересов русского народа [5]. Поэтому поддержка государства со стороны РПЦ придает легитимность светской власти даже без опоры на формальные демократические институты [34].

Исследователи подчеркивают социально-миротворческую миссию РПЦ, называют патриарха «социальным проповедником общероссийского национального масштаба», чья проповедь направлена на успокоение общественного сознания [18]. Подчеркивается, что в постсоветский период Церковь становится активным субъектом гражданского общества [15; 18; 34].

Итак, можно видеть, что исследование проблем ГЦО, в том числе отношения государства к деятельности РПЦ в духовно-нравственной сфере, активно развивается. Вместе с тем остается целый круг проблем, оставшихся без должного внимания авторов. Для объективного исследования необходимо расширять и круг изучаемых вопросов, и источниковую базу. В этой статье сделана попытка установить причины, по которым деятельность РПЦ по укреплению традиционных духовно-нравственных ценностей отвечает интересам верховной власти. Также предстоит осмыслить роль РПЦ в сфере развития ТДНЦ российского общества.

После развала СССР в постсоветской России перед властью встал вопрос о том, как выстраивать диалог с обществом. Государству для диалога был необходим признанный большинством выразитель интересов населения с высоким кредитом доверия. Этим выразителем была Церковь, которая с лета 
1993 до конца 1999 г. занимала первое место среди социальных институтов по уровню доверия россиян, опередив Президента и постоянно опережая армию [26].

На современном этапе Церковь играет значимую роль в обществе, ее влияние продолжает укрепляться. Если в 1989 г. православными верующими считали себя только 30\%, в 1994 г. таких было 56\%, а в 2008 г. уже 75\% [11], после чего этот показатель стабилизировался. До 75\% респондентов уверены, что в современном социуме религия играет «большую конструктивную и созидательную» роль. При этом, как считают современные исследователи, структура религиозных предпочтений россиян показывает, что их сознание однозначно склоняется в пользу исторической веры русского народа [23].

На разработку законодательно-правового поля ГЦО значительное влияние оказывает практический опыт их реализации, политическая культура населения. Так, Конституция 1993 г. зафиксировала предельно общие принципы взаимоотношений государства и Церкви [16]. Однако уже Федеральный закон «О свободе совести и религиозных объединениях» (1997), подтверждая светскость государства, тем не менее признал «особую роль православия в истории России, в становлении и развитии ее духовности и культуры» [32]. Первоначально вызывая споры, этот тезис в итоге стал общепринятым [30].

К 2015 г. в лексиконе власти все чаще встречаются такие понятия, как духовные ценности, культурно-нравственные ценности, общие ценности [30], традиционные нравственные ценности народов Российской Федерации [29] и др. Однако собственно понятие ТДНЦ впервые входит в лексику государственных документов только в 2015 г. Правительство определяет содержание ТДНЦ как «человеколюбие, справедливость, честь, совесть, воля, личное достоинство, вера в добро и стремление к исполнению нравственного долга перед самим собой, своей семьей и своим Отечеством» [25], затем президент добавляет к этому свой список: «приоритет духовного над материальным, защита человеческой жизни, прав и свобод человека, семья, созидательный труд, служение Отечеству, нормы морали и нравственности, гуманизм, милосердие, справедливость, взаимопомощь, коллективизм, историческое единство народов России, преемственность истории нашей Родины» [31].

Власть демонстрирует устойчивый интерес к укреплению ТДНЦ, сохранение и развитие которых находится в центре внимания действующей Стратегии национальной безопасности. В соответствии с документом, основой российского общества и общероссийской идентичности народов Российской Федерации провозглашается исторически сложившаяся система единых духовно-нравственных и культурно-исторических ценностей, а национальным интересом на долгосрочную перспективу - повышение качества преподавания основ религиозных культур, повышение роли школы в воспитании молодежи на основе ТДНЦ [там же]. 
В.В. Путин регулярно подчеркивает роль РПЦ в «упрочении нравственных опор» [8]. На встрече с патриархом Кириллом и участниками Архиерейского Собора Русской православной церкви в Кремле в 2013 г. он так обозначил свое ви́дение предпосылок и перспектив ГЦО в сфере ТДНЦ: «Русская православная церковь во все времена и эпохи всегда была со своим народом. Делила с ним все беды и все радости, поддерживала его и вдохновляла, скрепляла нравственный каркас общественной жизни, да и всей нашей национальной государственности... Мы рассчитываем на продолжение многогранного партнерства... Будем вместе с вами работать в деле укрепления согласия в нашем обществе, в укреплении его нравственного стержня... Это ответ на живую потребность людей в нравственной опоре, в духовном наставничестве и поддержке» [9]. Более того, президент называет семью и материнство, воспитание и образование детей, молодежную политику, присутствие при армии сферами, в которых Церковь должна получить все возможности для полноценного служения.

Обратим внимание, что не только первые лица, но и региональные лидеры также заинтересованы в деятельности РПЦ в сфере ТДНЦ. Например, мэр Москвы С.С. Собянин поддержал программу строительства православных храмов в столице, подчеркнув, что они становятся не только местами богослужений, но также общественными и социальными центрами для местных жителей: «Церковные общины ведут большую социальную работу, проводят благотворительные акции, помогают многодетным семьям, одиноким и пожилым людям, инвалидам и людям, страдающим алкогольной и наркотической зависимостью» [28]. Неслучайно в стратегии национальной политики города Москвы говорится о намерении сформировать культуру межнационального общения в соответствии с традиционными духовно-нравственными ценностями жителей [24].

Однако такой подход не встречает единодушной поддержки той части российской элиты, которая идентифицирует себя с частью глобального управляющего класса, обладая при этом финансовыми ресурсами, политическими и информационными рычагами внутри страны. В своей деятельности представители этой части общества склоняются к прагматическим интересам глобальной элиты $[10 ; 4]$. Интересы такой элиты - десуверенизация государств, стирание культурных и религиозных отличий, глобальное разделение труда, приватизация государственной собственности и природных ресурсов и т.п.

Среди представителей российской правящей элиты просматриваются два противоположных, но ситуативно пересекающихся вектора в их отношении к ГЦО. Государственники стремятся поддерживать Церковь, чтобы использовать ее растущее влияние для достижения властью мировоззренческого суверенитета. Глобалисты же стремятся редуцировать влияние Церкви на общество, максимально ослабить авторитет РПЦ. Но при этом глобалисты 
усматривают функциональную полезность Русской православной церкви в том, чтобы использовать ее влияние для смягчения социальной напряженности, вызванной радикальным имущественным расслоением общества [15]. Государственники видят в Русской православной церкви основания ТДНЦ, драйвер национального возрождения. Глобалисты же усматривают в ней успокоителя протестных настроений, прибежище беднеющей части общества, которой необходима психологическая и социальная помощь.

Однако в любом случае именно РПЦ представляется союзником власти в современной России, определяя ядро базовых ценностей и традиций, без которых невозможно долгосрочное поступательное развитие Российского государства и общества [14]. Кроме того, Церковь как носитель исторической памяти о единстве Российского государства оказывает цементирующее воздействие на свою каноническую территорию, замедляя процесс дезинтеграции некогда единого культурного, экономического, политического и языкового пространства.

Поскольку власть возлагает на Церковь большие надежды, у ряда исследователей сложилось мнение, что современная РПЦ крайне политизирована, что «Церковь предлагает государству и обществу политико-идеологические концепты, например идеологему “русский мир”» [2]. Конечно, отдельные иерархи так или иначе включены в политический процесс, кроме того, субъектом политики РПЦ делает ее большая недвижимость. Однако официально Церковь дистанцируется от политической активности.

Политические методы взаимодействия с государством и обществом не являются частью православного богословия. Православие не может быть втиснуто в рамки государственной идеологии, потому что идеология подразумевает разделение общества по политическим взглядам, Церковь же стремится к объединению людей. «Русская православная церковь не даст втянуть себя в политическую борьбу. Церковь должна сохранять автономность по отношению к государству, не должна становиться частью государственной машины или государственной политики. Она должна оставаться свободной, чтобы иметь возможность давать нравственную оценку, в том числе и деятельности власти», - утверждает патриарх Кирилл [19]. В «Основах социальной концепции Русской православной церкви» и в «Основах учения Русской православной церкви о свободе, достоинстве и правах человека» формулируется аналогичная позиция - от имени всей «церковной полноты»: Русская православная церковь лояльна государству, патриотична, аполитична, инклюзивна, миролюбива и социально полезна, отказывается брать на себя светскую власть, проповедует мир и соработничество людей с различными политическими взглядами. Патриотизм православного христианина должен быть действенным, проявляться в защите Отечества, труде на его благо, развитии национальной культуры и народного самосознания, а также в устроении 
народной жизни, и для мирян «в том числе, путем участия в делах государственного управления» [21;22].

Многие аспекты цивилизационного проекта России в XXI в. еще формируются. Но точно можно сказать, что в его основании лежат традиционные духовно-нравственные ценности. При этом, конечно, РПЦ не является единственным носителем этих ценностей. Так, В.В. Путин отмечал: «Наши традиционные конфессии - и буддисты, и христиане, и иудеи, и мусульмане, они в целом придерживаются, что касается базовых ценностей, нравственных, моральных ценностей, по сути, одних и тех же позиций. И, безусловно, это то, что нам вместе подлежит укреплять» [6].

Основные законодательные и концептуальные документы власти и практика их реализации показывает, что государству необходимо укрепление этих ценностей, поскольку именно они формируют жизненные идеалы и поведенческие установки граждан, структурируют социальные отношения, гармонизируют общественные и личные интересы. Соответственно, укрепление и развитие ТДНЦ - в интересах государственной безопасности [17]. В этом смысле деятельность РПЦ может способствовать консолидации общества и власти вокруг идеала сильного, справедливого государства, которое обеспечивает развитие национальных приоритетов, право граждан на свободу и человеческое достоинство.

\section{Библиография}

1. Алексеев А.В. Эволюция государственно-церковных отношений в условиях социально-политической трансформации российского общества (на примере Русской православной церкви). Автореф. дис. на канд. полит. наук. Орел: Среднерусский ин-т управления, 2018. 28 с.

2. Алексеев А.В. Гибридная модель государственно-церковных отношений в современной России // Власть. 2018. Т. 26. № 4. С. 25-28.

3. Багаева К.А., Чагдурова Э.Д. Государственно-религиозное взаимодействие в современном российском обществе // Исторические, философские, политические и юридические науки, культурология и искусствоведение. Вопросы теории и практики. Тамбов: Грамота, 2016. № 4 (66). Ч. 1. С. 25-28.

4. Брега А.В., Копылов И.А. Транснационализация политической элиты и влияние этого процесса на суверенитет государства // Власть. 2014. № 11. С. 77-83.

5. Верховский А. Национализм руководства Русской православной церкви в первое десятилетие XXI века // Православная церковь при новом патриархе. М.: РОССПЭН, 2012. C. $161-163$.

6. Вопрос прот. Максима Козлова Владимиру Путину // Православие и мир. 2011. 15 декабря. URL: https://www.pravmir.ru/vopros-prot-maksima-kozlova-vladimiru-putinu-o-razvitiiobrazovaniya/ (Дата обращения: 25.12.2018.)

7. ВЦИОМ: Большинство россиян считают чувства верующих важнее свободы слова // Взгляд. 2015. 13 августа. URL: http://vz.ru/news/2015/8/13/761023.html (Дата обращения: 26.05.2018.) 


\section{РАЗМЫШЛЕНИЯ, СООБЩЕНИЯ, КОММЕНТАРИИ}

8. Выступление Президента России В.В. Путина на торжествах по случаю 1030-летия Крещения Руси // Московский патриархат: Официальный сайт. 2018. 28 июля. URL: http:// www.patriarchia.ru/db/text/5244465.html (Дата обращения: 25.12.2018.)

9. Выступление Президента РФ В.В. Путина на встрече с участниками Архиерейского Собора Русской православной церкви // Московский патриархат: Официальный сайт. 2013. 1 фев. URL: http://www.patriarchia.ru/db/text/2767741.html (Дата обращения: 26.05.2018.)

10. Гончаров В.В. Влияние процессов глобализации на организацию и деятельность национальных политических элит // Российский гуманитарный журнал. 2017. Т. 6. № 3. C. 264-269.

11. Дубин Б., Малашенко А. Образ православного верующего в современной России // Московский центр Карнеги. 2012. 08 июня. URL: http://carnegie.ru/events/?fa=3725 (Дата обращения: 26.05.2018.)

12. Ершов Б.А. Социально-политическая деятельность Русской православной церкви на современном этапе развития общества // Вестник Воронежского государственного технического университета. 2013. Серия «Гуманитарные науки». Т. 9. № 2. С. 157-160.

13. Здоровец Я.И., Мухин А.А. Конфессии и секты в России. Религиозная, политическая и экономическая деятельность. М.: Алгоритм, 2005. 285 с.

14. Калгин М.В. Политические элиты и проблема национальной безопасности // Вопросы элитологии: философия, культура, политика. Сб. статей. Астрахань: Сорокин Р.В. 2015. C. $132-141$.

15. Катин В.И. Взаимоотношения Церкви и государства: статус-кво, перспективы // Теория и практика общественного развития. Краснодар: Издательский дом ХОРС, 2013. № 1. C. $277-282$.

16. Конституция РФ: Официальный сайт. URL: http://www.constitution.ru/index.htm (Дата обращения: 26.05.2018.)

17. Кудин В.А. Возможности использования духовного потенциала традиционных религий в воспитании будущих сотрудников правоохранительных органов // Вестник СанктПетербургского университета МВД России. 2013. № 1 (57). С. 4-8.

18. Лункин Р. Образ РПЦ в светских массмедиа // Православная церковь при новом патриархе. Сб. статей. М.: РОССПЭН, 2012. С. 171-222.

19. Мельников А., Мальцев В. Церковь дорожит свободой // НГ-Религия. 2011. 14 марта. URL: http://www.ng.ru/politics/2011-03-14/2_church.html (Дата обращения: 15.05.2017.)

20. Носовский Ю. Русь крещеная, но не просвещенная // Правда. ру. 2012. 19 декабря. URL: https://www.pravda.ru/faith/religions/orthodoxy/19-12-2012/1139329-levada_opros-0/ (Дата обращения: 26.05.2017.)

21. Основы социальной концепции Русской православной церкви. М.: Отдел внешних церковных связей Московского патриархата ОВЦС МП, 2008. 174 с.

22. Основы учения Русской православной церкви о свободе, достоинстве и правах человека // Московский патриархат: Официальный сайт. 2008. 26 июня. URL: http://www. patriarchia.ru/db/text/428616 (Дата обращения: 15.12.2018.)

23. Перепелкин Л.С., Стэльмах В.Г. Человек верующий: Религия и идентичность // Вопросы социальной теории. 2010. T. IV C. 373-395. URL: http://iphras.ru/uplfile/root/biblio/vst/ 2010/19.pdf (Дата обращения: 15.12.2018.)

24. Постановление Правительства Москвы от 6 июня 2016 г. № 312-ПП «О Стратегии национальной политики города Москвы на период до 2025 года» // ГАРАНТ. РУ. 2016. 14 июня. URL: http://www.garant.ru/products/ipo/prime/doc/71317676/\#ixzz5ZmbFaJzT (Дата обращения: 15.12.2018.) 
25. Распоряжение Правительства РФ от 29.05.2015 № 996-р «Об утверждении Стратегии развития воспитания в Российской Федерации на период до 2025 года» // КонсультантПлюс. URL: http://www.consultant.ru/document/cons_doc_LAW_180402/ (Дата обращения: 15.12.2018.)

26. Синелина Ю.Ю. Атака на РПЦ? // Социс. 2001. № 11. С. 100-104. URL: http:// ecsocman.hse.ru/data/461/704/1217/016Sinelina.pdf (Дата обращения: 06.12.2018.)

27. Стенограмма встречи председателя Правительства РФ В.В. Путина со Святейшим Патриархом Кириллом и лидерами традиционных религиозных общин России // Московский патриархат: Официальный сайт. 2012. 8 февр. URL: http://www.patriarchia.ru/db/text/ 2005767.html (Дата обращения: 26.04.2018.)

28. Тезисы из выступления мэра Москвы С.С. Собянина на VIII заседании Попечительского совета Фонда «Поддержки строительства храмов города Москвы». 2018. 20 сент. // РПЦ. Финансово-хозяйственное управление: Официальный сайт. URL: http://www.fedmp.ru/news/ tezisy-iz-vystupleniya-mera-moskvy-sergeya-semenovicha-sobyanina-na-viii-zasedanii-popechitelskogosoveta-fonda-podderzhki-stroitelstva-hramov-goroda-moskvy/ (Дата обращения: 15.12.2018.)

29. Указ Президента РФ от 19 декабря 2012 г. № 1666 «О Стратегии государственной национальной политики Российской Федерации на период до 2025 года» // ГАPAHT. URL: http://base.garant.ru/70284810/\#ixzz5ZmV8vFsL (Дата обращения: 15.12.2018.)

30. Указ Президента РФ от 24 декабря 2014 г. № 808 «Об утверждении Основ государственной культурной политики» // ГАРАНТ. URL: http://base.garant.ru/70828330/\#ixzz5Zmhh M9XR (Дата обращения: 15.12.2018.)

31. Указ Президента РФ от 31.12.2015 № 683 «О Стратегии национальной безопасности Российской Федерации» // КонсультантПлюс. URL: http://www.consultant.ru/document/cons doc_LAW_191669/ (Дата обращения: 15.12.2018.)

32. Федеральный закон «О свободе совести и о религиозных объединениях» от 26.09.1997 № 125-Ф3 // КонсультантПлюс. URL: http://www.consultant.ru/document/cons_doc_LAW_16218 (Дата обращения: 15.12.2018.)

33. Филатов С. Патриарх Кирилл: два года планов, мечтаний и неудобной реальности // Православная церковь при новом патриархе. М.: РОССПЭН, 2012. С. 9-10.

34. Шишков А. Некоторые аспекты десекуляризации в постсоветской России // Государство, религия, церковь в России и за рубежом. 2012. № 2. С. 165-177.

35. Штёкль К. Постсекулярные конфликты и глобальная борьба за традиционные ценности (лекция) // Государство, религия, церковь в России и за рубежом. 2016. № 4. С. 222-240.

\section{References}

Alekseev A.V. Jevoljucija gosudarstvenno-cerkovnyh otnoshenij $\mathrm{v}$ uslovijah social'nopoliticheskoj transformacii rossijskogo obshhestva (na primere russkoj pravoslavnoj cerkvi). Avtoref. dis. na.... kand. polit. nauk. Orel: Srednerusskij in-t upravlenija, 2018. 28 p.

Alekseev A.V. Gibridnaja model' gosudarstvenno-cerkovnyh otnoshenij v sovremennoj Rossii // Vlast'. 2018. Vol. 26. N 4. P. 25-28.

Bagaeva K.A., Chagdurova Je.D. Gosudarstvenno-religioznoe vzaimodejstvie v sovremennom rossijskom obshhestve // Istoricheskie, filosofskie, politicheskie i juridicheskie nauki, kul'turologija i iskusstvovedenie. Voprosy teorii i praktiki. Tambov: Gramota, 2016. N 4 (66). Ch. 1. P. 25-28.

Brega A.V., Kopylov I.A. Transnacionalizacija politicheskoj jelity i vlijanie jetogo processa na suverenitet gosudarstva // Vlast'. 2014. N 11. P. 77-83.

Verhovskij A. Nacionalizm rukovodstva Russkoj pravoslavnoj cerkvi v pervoe desjatiletie XXI veka // Pravoslavnaja cerkov' pri novom patriarhe. Moscow: ROSSPJeN, 2012. P. 161-163. 


\section{РАЗМЫШЛЕНИЯ, СООБЩЕНИЯ, КОММЕНТАРИИ}

Vopros prot. Maksima Kozlova Vladimiru Putinu // Pravoslavie i mir. 2011. Dec. 15. URL: https://www.pravmir.ru/vopros-prot-maksima-kozlova-vladimiru-putinu-o-razvitii-obrazovaniya/ (Data obrashhenija: 25.12.2018.)

VCIOM: Bol'shinstvo rossijan schitajut chuvstva verujushhih vazhnee svobody slova // Vzgljad. 2015. Aug. 13. URL: http://vz.ru/news/2015/8/13/761023.html (Data obrashhenija: 26.05.2018.)

Vystuplenie Prezidenta Rossii V.V. Putina na torzhestvah po sluchaju 1030-letija Kreshhenija Rusi // Moskovskij patriarhat: Official Website. 2018. 28 July. URL: http://www.patriarchia. $\mathrm{ru} / \mathrm{db} / \mathrm{text} / 5244465 . h t m l$ (Data obrashhenija: 25.12.2018.)

Vystuplenie Prezidenta RF V.V. Putina na vstreche s uchastnikami Arhierejskogo Sobora Russkoj Pravoslavnoj Cerkvi // Moskovskij patriarhat: 28 July. 2013. Feb. 1. URL: http://www. patriarchia.ru/db/text/2767741.html (Data obrashhenija: 26.05.2018.)

Goncharov V.V. Vlijanie processov globalizacii na organizaciju i dejatel'nost' nacional'nyh politicheskih jelit // Rossijskij gumanitarnyj zhurnal. 2017. Vol. 6. N 3. P. 264-269.

Dubin B., Malashenko A. Obraz pravoslavnogo verujushhego v sovremennoj Rossii // Moskovskij centr Karnegi. 2012. July 8. URL: http://carnegie.ru/events/?fa=3725 (Data obrashhenija: 26.05.2018.)

Ershov B.A. Social'no-politicheskaja dejatel'nost' Russkoj pravoslavnoj cerkvi na sovremennom jetape razvitija obshhestva // Vestnik Voronezhskogo gosudarstvennogo tehnicheskogo universiteta. 2013. Serija «Gumanitarnye nauki». Vol. 9. N 2. P. 157-160.

Zdorovec Ja.I., Muhin A.A. Konfessii i sekty v Rossii. Religioznaja, politicheskaja i jekonomicheskaja dejatel'nost'. Moscow: Algoritm, 2005. 285 p.

Kalgin M.V. Politicheskie jelity i problema nacional'noj bezopasnosti // Voprosy jelitologii: filosofija, kul'tura, politika. Sb. statej. Astrahan': Sorokin R.V. 2015. P. 132-141.

Katin V.I. Vzaimootnoshenija Cerkvi i gosudarstva: status-kvo, perspektivy // Teorija i praktika obshhestvennogo razvitija. Krasnodar: Izdatel'skij dom HORS, 2013. N 1. P. 277-282.

Konstitucija RF: Official Website. URL: http://www.constitution.ru/index.htm (Data obrashhenija: 26.05.2018.)

Kudin V.A. Vozmozhnosti ispol'zovanija duhovnogo potenciala tradicionnyh religij v vospitanii budushhih sotrudnikov pravoohranitel'nyh organov // Vestnik Sankt-Peterburgskogo universiteta MVD Rossii. 2013. N 1 (57). P. 4-8.

Lunkin R. Obraz RPC v svetskih massmedia // Pravoslavnaja cerkov' pri novom patriarhe. Sb. statej. Moscow: ROSSPJeN, 2012. P. 171-222.

Mel'nikov A., Mal'cev V. Cerkov' dorozhit svobodoj // NG-Religija. 2011. March 14. URL: http://www.ng.ru/politics/2011-03-14/2_church.html (Data obrashhenija: 15.05.2017.)

Nosovskij Ju. Rus' kreshhenaja, no ne prosveshhennaja // Pravda.ru. 2012. Dec. 19. URL: https://www.pravda.ru/faith/religions/orthodoxy/19-12-2012/1139329-levada_opros-0/ (Data obrashhenija: 26.05 .2017$.

Osnovy social'noj koncepcii russkoj pravoslavnoj cerkvi. Moscow: Otdel vneshnih cerkovnyh svjazej Moskovskogo Patriarhata OVCS MP, 2008. 174 p.

Osnovy uchenija Russkoj Pravoslavnoj Cerkvi o svobode, dostoinstve i pravah cheloveka // Moskovskij patriarhat: Official Website. 2008. Jun 26. URL: http://www.patriarchia.ru/db/text/ 428616 (Data obrashhenija: 15.12.2018.)

Perepelkin L.S., Stjel'mah V.G. Chelovek verujushhij: Religija i identichnost' // Voprosy social'noj teorii. 2010. Vol. IV. P. 373-395. URL: http://iphras.ru/uplfile/root/biblio/vst/2010/19.pdf (Data obrashhenija: 15.12.2018.)

Postanovlenie Pravitel'stva Moskvy ot 6 ijunja 2016 g. N 312-PP «O Strategii nacional'noj politiki goroda Moskvy na period do 2025 goda» // GARANT.RU. 2016. June 14. URL: 
http://www.garant.ru/products/ipo/prime/doc/71317676/\#ixzz5ZmbFaJzT (Data obrashhenija: 15.12.2018.)

Rasporjazhenie Pravitel'stva RF ot 29.05.2015 № 996-r «Ob utverzhdenii Strategii razvitija vospitanija v Rossijskoj Federacii na period do 2025 goda» // Konsul'tantPljus. URL: http://www. consultant.ru/document/cons_doc_LAW_180402/ (Data obrashhenija: 15.12.2018.)

Sinelina Ju.Ju. Ataka na RPC? // Socis. 2001. N 11. P. 100-104. URL: http:// ecsocman.hse.ru/data/461/704/1217/016Sinelina.pdf (Data obrashhenija: 06.12.2018.)

Stenogramma vstrechi predsedatelja Pravitel'stva RF V.V. Putina so Svjatejshim Patriarhom Kirillom i liderami tradicionnyh religioznyh obshhin Rossii // Moskovskij patriarhat: Official Website. 2012. Feb. 8. URL: http://www.patriarchia.ru/db/text/2005767.html (Data obrashhenija: 26.04.2018.)

Tezisy iz vystuplenija mjera Moskvy S.S. Sobjanina na VIII zasedanii Popechitel'skogo soveta Fonda «Podderzhki stroitel'stva hramov goroda Moskvy» // RPC. Finansovo-hozjajstvennoe upravlenie: Official Website. 2018. Sept. 20. URL: http://www.fedmp.ru/news/tezisy-iz-vystupleniya-meramoskvy-sergeya-semenovicha-sobyanina-na-viii-zasedanii-popechitelskogo-soveta-fonda-podderzhkistroitelstva-hramov-goroda-moskvy/ (Data obrashhenija: 15.12.2018.)

Ukaz Prezidenta RF ot 19 dekabrja 2012 g. N 1666 «O Strategii gosudarstvennoj nacional'noj politiki Rossijskoj Federacii na period do 2025 goda»// GARANT. URL: http://base.garant.ru/ 70284810/\#ixzz5ZmV8vFsL (Data obrashhenija: 15.12.2018.)

Ukaz Prezidenta RF ot 24 dekabrja 2014 g. N 808 «Ob utverzhdenii Osnov gosudarstvennoj kul'turnoj politiki»// GARANT. URL: http://base.garant.ru/70828330/\#ixzz5ZmhhM9XR (Data obrashhenija: 15.12 .2018 .)

Ukaz Prezidenta RF ot 31.12.2015 N 683 «O Strategii nacional'noj bezopasnosti Rossijskoj Federacii»// Konsul'tantPljus. URL: http://www.consultant.ru/document/cons_doc_LAW_191669/ (Data obrashhenija: 15.12.2018.)

Federal'nyj zakon «O svobode sovesti i o religioznyh ob'edinenijah» ot 26.09.1997 N 125-FZ // Konsul'tantPljus. URL: http://www.consultant.ru/document/cons_doc_LAW_16218 (Data obrashhenija: 15.12.2018.)

Filatov S. Patriarh Kirill: dva goda planov, mechtanij i neudobnoj real'nosti // Pravoslavnaja cerkov' pri novom patriarhe. Moscow: ROSSPJeN, 2012. P. 9-10.

Shishkov A. Nekotorye aspekty desekuljarizacii v postsovetskoj Rossii // Gosudarstvo, religija, cerkov' v Rossii i za rubezhom. 2012. N 2. P. 165-177.

Shtjokl' K. Postsekuljarnye konflikty i global'naja bor'ba za tradicionnye cennosti (lekcija) // Gosudarstvo, religija, cerkov' v Rossii i za rubezhom. 2016. N 4. P. 222-240. 